\title{
Using $5 \mathrm{~W}-1 \mathrm{H}$ and $4 \mathrm{M}$ Methods to Analyse and Solve the Problem with the Visual Inspection Process - case study
}

\author{
Krzysztof Knop ${ }^{1, *}$, and Krzysztof Mielczarek ${ }^{1}$ \\ ${ }^{1}$ Technical University of Czestochowa, Faculty of Management, Department of Production \\ Engineering and Safety, 42-200 Czestochowa, Poland
}

\begin{abstract}
The article presents a case study on the use of specially prepared $5 \mathrm{~W}-1 \mathrm{H}$ and $4 \mathrm{M}$ sheets for the analysis of the problem during the visual inspection process of the electric device, in order to solve it. The identified problem was related to inconsistent assessments during the visual (alternative) inspection of chamber gaps of the electric switch. The research methodology was presented the same as results confirming the effectiveness of the problem analysis in the area of quality control by using these two methods of Lean and WCM concepts. The article aimed to show that a skilful and pragmatic approach to the problem supported by appropriate tools can contribute to its effective solution.
\end{abstract}

\section{Introduction}

Visual inspection is the most common variant of alternative control of the product [1], where the product is assessed on the basis of measurable or non-measurable features and its result is classification of product to one of two $(\mathrm{OK}, \mathrm{nOK})$ or several quality categories [2]. The main purpose of the visual inspection is to ensure that the product will be free from nonconformities and defects when it is forwarded to the next steps of the process or to the user [3]. Visual inspection is particularly important in the case of processes whose repeatability and reproducibility are limited, and the process results differ and require an individual approach when assessing the quality of their performance [4]. The condition for the effectiveness of visual inspection is the knowledge of errors that can potentially be found at a given inspection station and a clear definition of the inspection criteria (how many and what types of nonconformities cause the product to be considered as nonconforming).

Visual inspection, in particular in the organoleptic version, is an error-prone inspection method due to the high proportion of the human factor [3-5]. Errors in visual inspection are unfortunately unavoidable. In the visual assessment, the controller may commit two types of errors, i.e. accepts an nonconforming product (II ${ }^{\text {nd }}$ type error) or rejects a conforming product ( $\mathrm{I}^{\text {st }}$ type error). The reasons for these errors can be very different, dependent or independent of the controller itself (related to, for example, work organization, work time,

* Corresponding author: krzysztof.knop@wz.pcz.pl 
workstation organization, time of inspection, etc.) [4-8], but they can be grouped into 4 or $5 \mathrm{M}$ categories (i.e. Material, Machine, Method, Man, Management), which come from the Ishikawa diagram [9]. The consequences of errors in visual inspection are costs, and in the worst case the decline of the company's reputation in the eyes of customers and decrease in sales (in the case while nonconforming product getting into the customer - as a result of the II $^{\text {nd }}$ type of error) [10-11]. Analysis of losses and errors should be based on the cost criterion [10]. In effects visual control process, like any other process, should be subject to random changes (random variation) [13]. The large variability of internal and external factors is a serious problem hampering production management [14].

Every error or other problem occurring during or after visual inspection processes should be thoroughly analysed. To solve the problem permanently, one should understand in depth the situations and reach the source causes of the problem. For this purpose, tools from the Lean and WCM concepts, i.e. 5W1H and 4M method, can be used.

\section{Aim and scope}

The aim of the article is to analyse and solve the problem related to low effectiveness of visual inspection of the product - an electrical switch, more precisely one of the characteristics of its element - slots in the chambers, by using specially prepared sheets supporting analysis with the use of $5 \mathrm{~W} 1 \mathrm{H}$ and $4 \mathrm{M}$ methods.

\section{Methodology}

The paper presents the practical use of two methods in the field of analysis and problem solving in visual inspection process, i.e. $5 \mathrm{~W} 1 \mathrm{H}$ and $4 \mathrm{M}$ methods.

The $5 \mathrm{~W} 1 \mathrm{H}$ method is a direct reference to the rules: "if you don't ask, you won't find out", "the problem well described is a half-solved problem". It is used in describing and analysing a given problem by answering 5 questions beginning with the $\mathrm{W}$ letter (What, Where, When, Who, Which) and 1 question beginning with the H letter (How). Due to the fact that all questions are open, i.e. none of them can be answered YES or NO, they do not allow to stick to one aspect of a given problem, but show different "sides of the coin". The $5 \mathrm{~W} 1 \mathrm{H}$ method alone will not solve the problem, but it creates the conditions for the proper identification of the problem under analysis [9].

The $4 \mathrm{M}$ is a method that allows to identify and group causes that impact to a specific effect. 4M categories (Material, Method, Machine, Man) are often used in the Cause-Effect Diagram created by Kaoru Ishikawa [9]. It is a good, intermediate tool of problem analysis.

Both, the 5W1H and 4M methods can be used independently of each other, as well as together in relation to a given problem. By the use of these methods it could be analyse any production, service or management problem. They are tools used in Lean and WCM concepts [15]. There are some examples of the use of these methods, based on special sheets, for the analysis of production problems (especially in quality, maintenance), but it was noticed lack of dedicated sheets for quality control processes. I decided to fill this gap. The inspiration to create such sheets was their successfully used versions in the FCA Canada car factory - Windsor Assembly in Ontario, Canada.

The analysed problem, which was decided to deal with the use of $5 \mathrm{~W} 1 \mathrm{H}$ and $4 \mathrm{M}$ method, was the problem of inconsistent assessments during visual inspection of the electrical switch. The analysed product - an electric switch is a product produced in a factory in Malopolska (one of the regions in Poland). Its task is (after adapting with the accessory) to disconnect the power supply in the event of an overload in the mains. 


\section{Analysis and results}

First, after identifying the problem - inconsistent assessments during the visual inspection, it was decided to analyse it using the $5 \mathrm{~W} 1 \mathrm{H}$ method. The purpose of using the $5 \mathrm{~W} 1 \mathrm{H}$ method was to examine in detail the analysed problem, before the next stage of the analysis, i.e. looking for the cause or causes of the problem using the $4 \mathrm{M}$ method. The result of applying the $5 \mathrm{~W} 1 \mathrm{H}$ method to the analysed problem was shown in Table 1.

Table 1. 5W1H Analysis Sheet to Describe the Problem in the Quality Control Process in more detail.

\begin{tabular}{|c|c|c|}
\hline \multicolumn{3}{|c|}{$\begin{array}{l}\text { Initial Description of the Problem: Inconsistent assessment of the size of the chambers gaps } \\
\text { during visual inspection }\end{array}$} \\
\hline $5 \mathrm{~W} 1 \mathrm{H}$ & Consider These Questions (“Q"): & Answer As Many “Q" As You Can! \\
\hline What & $\begin{array}{l}* \text { What does the problem look like? } \\
* \text { Is the problem related to Ist type or } \\
\text { II } \\
\text { * During the production of which } \\
\text { model / version of the product did } \\
\text { the problem take place? }\end{array}$ & $\begin{array}{l}\text { The problem is the lack of coherence in the } \\
\text { assessments of the appraisers performing } \\
\text { the visual inspection of the gaps. It applies } \\
\text { to both errors of type I and type II. It occurs } \\
\text { during visual inspection of slots in the } \\
\text { chambers of the electrical switch C1. }\end{array}$ \\
\hline When & $\begin{array}{l}\text { * When did the problem occur? } \\
\text { * When in the sequence of } \\
\text { inspection: initial, first piece, self- } \\
\text { control, inter-operative, final? } \\
\text { * At what time and in what period? }\end{array}$ & $\begin{array}{l}\text { The problem arises at every stage of the } \\
\text { control process in which the size of the gaps } \\
\text { is controlled. }\end{array}$ \\
\hline Where & $\begin{array}{l}\text { * Where did the problem occur? } \\
\text { * Where was the problem detected? } \\
\text { * In relation to which product's } \\
\text { characteristic/nonconformity in } \\
\text { particular the problem occurred? }\end{array}$ & $\begin{array}{l}\text { The problem arises at } 5 \text { control stations: } \\
\text { quality controllers, leaders from the } \\
\text { Compact line, leaders from the line of } \\
\text { chambers, trainers from the Compact line, } \\
\text { trainers from the line of chambers and } \\
\text { setters from the chamber line. The problem } \\
\text { was detected in the next stages of the } \\
\text { control process, in the final control as well } \\
\text { as by the client. }\end{array}$ \\
\hline Who & $\begin{array}{l}\text { * Who does it affect? Everyone? } \\
\text { * Is problem affected by human } \\
\text { factor? } \\
\text { * Is problem caused by operator } \\
\text { error-QCD employee error-other } \\
\text { error? } \\
\text { * Is the problem related to specific } \\
\text { controllers' skill? } \\
\text { * Is the problem related to special } \\
\text { abilities? } \\
\text { * Could any specific behaviour cause } \\
\text { the problem? } \\
\text { * Do only some self-controllers } \\
\text { (operators) had this problem? } \\
\text { * Is the problem occurred only on } \\
\text { some changes? } \\
\text { * Do QC department controllers } \\
\text { show a problem but self-controllers } \\
\text { (operators) not or vice versa? }\end{array}$ & $\begin{array}{l}\text { All persons who have been in contact with } \\
\text { the chamber tightness check are involved in } \\
\text { the problem. It is the result of errors of } \\
\text { operators, leaders and employees of the } \\
\text { quality control department (QCD). It is } \\
\text { associated with specific assessment abilities } \\
\text { in the scope of reading the requirements } \\
\text { given in the process standard. The ability to } \\
\text { read and interpret these requirements } \\
\text { affects on the effectiveness of the visual } \\
\text { inspection. The problem related to the } \\
\text { uncertainty of decisions regarding } \\
\text { qualification of the product to qualitative } \\
\text { categories (OK, nOK) is demonstrated by } \\
\text { operators, leaders and employees of the } \\
Q C D .\end{array}$ \\
\hline Which & $\begin{array}{l}* \text { Which trend or pattern does the } \\
\text { problem have? } \\
\text { * Does the problem happen by }\end{array}$ & $\begin{array}{l}\text { The problem appears chronically, it occurs } \\
\text { practically on every shift (there were errors } \\
\text { related to it). The frequency of this problem } \\
\text { varies with each shift. }\end{array}$ \\
\hline
\end{tabular}




\begin{tabular}{|c|c|c|}
\hline & $\begin{array}{l}\text { accident or does it have a tendency } \\
\text { or is it related to something? } \\
\text { * How often does the problem occur? } \\
\text { * Every hour, every shift, every day, } \\
\text { once a month? } \\
\text { * Does the problem happen in any } \\
\text { particular direction? }\end{array}$ & \\
\hline How & $\begin{array}{l}\text { * How is the state of the product } \\
\text { changed from the optimal? } \\
\text { * How many times does the problem } \\
\text { occur? } \\
\text { * What consequences (\& quality, } \\
\text { cost, safety) are related to the } \\
\text { problem? }\end{array}$ & $\begin{array}{l}\text { The consequence of errors is that the } \\
\text { conforming products are considered as } \\
\text { nonconforming and vice versa, appearing } \\
\text { false alarms and production is stopped, } \\
\text { overregulation of the threader and } \\
\text { ultimately high value of NQC. }\end{array}$ \\
\hline \multicolumn{3}{|c|}{$\begin{array}{l}\text { Revised Description of the Problem: Lack of consistency of assessments during visua } \\
\text { inspection of the gap size of the C1 chambers, related to the } I^{\text {st }} \text { and } I^{\text {nd }} \text { type of errors, at each } \\
\text { stage of the inspection process, in which this characteristic is inspected, related to each } \\
\text { appraisers, appearing chronically, generating high costs. }\end{array}$} \\
\hline
\end{tabular}

After thoroughly defining the examined problem, the root causes of its occurrence were identified and analyzed by the use of the $4 \mathrm{M}$ method (an approach to this analysis in the Windsor Assembly in Ontario, Canada was used). In the next step, based on the information from the $5 \mathrm{~W}-1 \mathrm{H}$ method, the possible causes of problem in the analysed area have been defined. The most probable causes of the problem were marked with the red frame in "4M box" and transferred to the Ishikawa diagram (Fig. 1). The indicated causes were verified by the $3 \mathrm{G}$ type analysis. Next, the causes that had impact to the problem were marked with a red frame on the Ishikawa diagram, after their verification. Other causes have been deleted. The best corrective actions for root causes have been marked (Table 2).

Table 2. 4M Analysis Sheet to Describe the Problem in the Quality Control Process.

\begin{tabular}{|c|c|}
\hline Man: & $\begin{array}{l}\text { "Training, Experience, Qualification" } \\
\text { "Knowledge of QC process, standards" } \\
\text { "Following the Standards/SOP/OPL" }\end{array}$ \\
\hline Potential Root Causes & Possible Corrective Actions \\
\hline $\begin{array}{l}\text { Unfamiliar with Some } \\
\text { Elements of the Job }\end{array}$ & \begin{tabular}{|l|} 
Train of Unfamiliar Elements \\
Review Standards/SOP/OPL \\
\end{tabular} \\
\hline \multirow{2}{*}{$\begin{array}{l}\text { Elements of the Job Not } \\
\text { Taught }\end{array}$} & Train the EIenterts of the fot \\
\hline & Review Standards/SOP/OPL \\
\hline \multirow{2}{*}{$\begin{array}{l}\text { Not Trained on Visual } \\
\text { Aids/Standard Usage }\end{array}$} & Train on how to use the visual aids \\
\hline & Review Standards/SOP/OPL \\
\hline \multirow{4}{*}{$\begin{array}{l}\text { Not Following } \\
\text { Standards/SOP/OPL (All } \\
\text { Shifts) }\end{array}$} & Review Standards/SOP/OPL \\
\hline & Post Standards/SOP/OPL in Job Station \\
\hline & Review Flex Charts/Training Matrix \\
\hline & Implement LPA for Critical Craftsmanship Elements \\
\hline \multirow{2}{*}{$\begin{array}{l}\text { Is Irresponsible (you can } \\
\text { not count on him) }\end{array}$} & Conversation with the employee \\
\hline & Coaching \\
\hline \multirow{3}{*}{$\begin{array}{l}\text { Inadequate } \\
\text { Qualifications/Insufficient } \\
\text { Experience }\end{array}$} & Review Flex Charts/Training Matrix \\
\hline & Participation in Training \\
\hline & \begin{tabular}{|l}
$\begin{array}{l}\text { Using other forms of improving qualifications } \\
\text { (study, others) }\end{array}$ \\
\end{tabular} \\
\hline \multirow{3}{*}{$\begin{array}{l}\text { Does not Maintain Good } \\
\text { Interpersonal Relations }\end{array}$} & Conversation with the employee \\
\hline & Coaching \\
\hline & $\begin{array}{l}\text { Team building (integration games, trip, discussions, } \\
\text { exercises) }\end{array}$ \\
\hline \multirow{4}{*}{$\begin{array}{l}\text { Poor personal } \\
\text { mental/physical state }\end{array}$} & Review the medical examinations \\
\hline & Referral for medical examination \\
\hline & $\begin{array}{l}\text { Analysis corelletion between wrong physical/mental } \\
\text { state \& work environment }\end{array}$ \\
\hline & Ensuring safe and hygienic working conditions \\
\hline Other cause: & \\
\hline
\end{tabular}

\begin{tabular}{|c|c|}
\hline \multirow{3}{*}{ Method: } & "Craftsmanship - The Knack" \\
\hline & "Best Inspection Sequence or Standard" \\
\hline & "Inspection Complexity", "Inspection Condition" \\
\hline Potential Root Causes & Possible Corrective Actions \\
\hline \multirow{5}{*}{$\begin{array}{l}\text { Process Standard is } \\
\text { Incorrect }\end{array}$} & Specify Best Inspection Sequence \\
\hline & Specify Best Inspection Tool \\
\hline & Specify Best Way to Jooso Tod \\
\hline & Update Standard/SOP/OPL \\
\hline & Implement LPA for Critical Craftsmanship Elementer \\
\hline \multirow[t]{4}{*}{$\begin{array}{l}\text { Inspection process is } \\
\text { complex }\end{array}$} & $\begin{array}{l}\text { Complete Mura Action to Beternmine Corrective } \\
\text { Action }\end{array}$ \\
\hline & Rebalance Job Elements \\
\hline & Implement Downstream Validation \\
\hline & Implement Mistake Proofing \\
\hline $\begin{array}{l}\text { Inspection method is not } \\
\text { effective (does it ensure } \\
\text { that only a good product is } \\
\text { handed over to the next } \\
\text { operation) }\end{array}$ & $\begin{array}{l}\text { Evaluate the effectiveness of the inspection process } \\
\text { (MSA approach) to Determine Corrective Action }\end{array}$ \\
\hline $\begin{array}{l}\text { Temperature and humidity } \\
\text { are not appropriate }\end{array}$ & $\begin{array}{l}\text { Measure the Level of Temperature and Humidity } \\
\text { and Physical Ailments Associated with It to } \\
\text { Determine Corrective Action }\end{array}$ \\
\hline $\begin{array}{l}\text { Lighting and ventilation } \\
\text { are not adequate }\end{array}$ & $\begin{array}{l}\text { Measure the Level of Lighting and Ventilation and } \\
\text { Physical Ailments Associated with It to Determine } \\
\text { Corrective Action }\end{array}$ \\
\hline $\begin{array}{l}\text { Work station is not } \\
\text { ergonomic }\end{array}$ & $\begin{array}{l}\text { Evaluate Physical Discomfort During the Inspection } \\
\text { to Determine Corrective Action }\end{array}$ \\
\hline Other cause: & \\
\hline
\end{tabular}




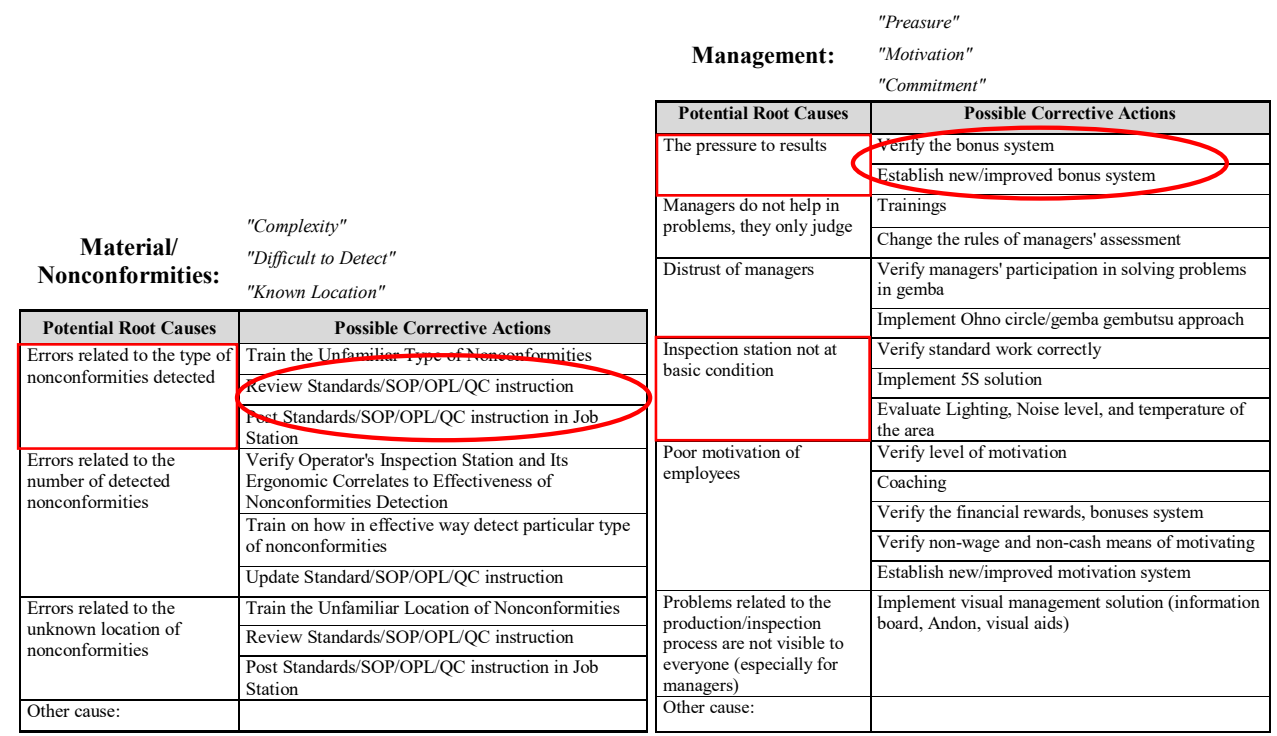

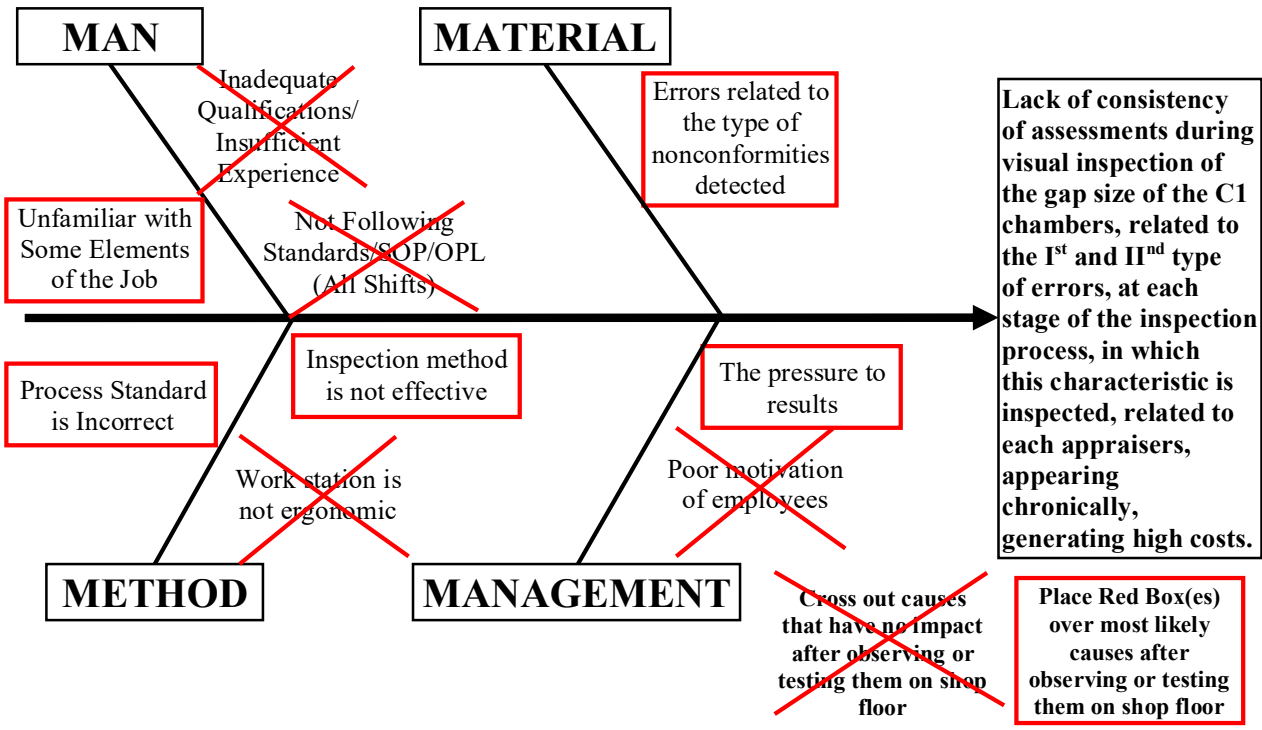

Fig. 1. Ishikawa diagram to analyse the problem with the visual inspection process.

\section{Conclusions}

The analysis carried out using the $5 \mathrm{~W} 1 \mathrm{H}$ and $4 \mathrm{M}$ methods showed that the problem with the lack of coherence of gaps assessments is on the side of imprecise documentation describing this activity. Hence, employees making such control interpreted the size of the gaps differently. During the investigation (as part of the MSA procedure) it was noticed that not all operators used feeler gauges in the case of doubts about the permissible size of gaps, and those who did it, used it in different ways. Some of them inserted a feeler gauge gently, and when the resistance appeared, they stopped further evaluation and others tried to move the gauge over the entire length of joining the housings. It was shown that the leaders of the 
Compact line were more restrictive to the control, but this was the result of fear of rejection of dubious chambers on the line of main assembly. In turn, the leaders of the chamber lines approached the control more liberally, i.e. more chambers were not allowed for further production than it should. Interviews conducted among the appraisers showed that a large group of people could not precisely specify the distances in which the $0.05 \mathrm{~mm}$ feeler gauge should stop. In addition, the rejection of questionable chambers also resulted from the fear of rejecting them at the next stage of the control. Passing the defective product and detecting this fact in the next stage resulted in lowering the value of the quarterly bonus. It was easier for all appraiser groups to consider the dubious chamber as nonconforming and dismantle it, generating losses on the NQC.

In order to solve the problem, a visual pattern was created with marked zones in which a section of at least $2 \mathrm{~mm}$ in length with no gap was to be found and all people were trained out to use it. There have been changes in the standard documentation used during a visual inspection, a more clarifying and explaining "contentious issues" with the use of visual elements (images). Also, persons responsible for the replacement of used feeler gauges for new ones were established. The corrective actions introduced have brought the intended effect - the number of errors and the amount of related costs have been significantly reduced.

\section{References}

1. R. G. Rosandich, Intelligent Visual Inspection. Using artificial neural networks, (Chapman \& Hall, London, 1997)

2. S. Borkowski, K. Knop, MPER 7, 3 (2016)

3. K. Knop, M. Ingaldi, M. Smilek-Starczynowska, Lecture Notes in Mechanical Engineering, Advances in Manufacturing (Springer Inter. Pub., Cham, 2018)

4. K. Vogt, A. Kujawińska, Inżynieria Maszyn, 18, 1 (2013)

5. A. Kujawińska, K. Vogt, MPER 6, 2 (2015)

6. K. Vogt, A. Kujawińska, Innowacje w zarzadzaniu i inżynierii produkcji, 2 (2014)

7. M. Diering, K. Dyczkowski, International Conference on Industrial Engineering and Engineering, Assesing the Raters Agreement in the Diagnostic Catheter Tube Connector Production Process Using Novel Fuzzy Similarity Coefficient, (IEEM, 2016)

8. R. Nakajima, K. Shida, T. Matsumoto, APMS 2013, Part I, IFIP AICT 414, 29-39 (2013)

9. B. Starzyńska, A. Hamrol, Tot. Qual. Man. and Bus. Exc. 24, 5-6, 577-595 (2013)

10. A. Pacana, R. Ulewicz, Pol. J. of Manag. Stud. 16, 1 (2017)

11. M. Nowicka-Skowron, R. Ulewicz, METAL 2015, 24th International Conference on Metallurgy and Materials, Quality management in logistics processes in metal branch, in (Tanger Ltd., Ostrava, 2015)

12. A. Maszke, Production Engineering Archives 17 (2017)

13. S. Borkowski, M. Ingaldi, METAL 2015, 24th International Conference on Metallurgy and Materials, Brno, 2015)

14. J. Trojanowska, K. Zywicki, E. Pajak, Information Technologies in Environmental Engineering: new trends and challenges (Springer Verlag, 2011)

15. F. De Felice, A. Petrillo, S. Monfreda, Operations Management (Intech, 2013) 